\title{
Bodies, Shrines, and Roads: violence, (im)mobility and displacement in Sri Lanka
}

\author{
JENNIFER HYNDMAN ${ }^{\mathrm{a}}$ and MALATHI DE ALWIS ${ }^{\mathrm{b}}$ \\ ${ }^{a}$ Department of Geography, Simon Fraser University, Canada \\ ${ }^{\mathrm{b}}$ Senior Research Fellow, International Centre for Ethnic Studies, Colombo, Sri Lanka
}

\begin{abstract}
In Sri Lanka, gender and national identities intersect to shape people's mobility and security in the context of conflict. This article aims to illustrate the gendered processes of identity construction in the context of competing militarised nationalisms. We contend that a feminist approach is crucial, and that gender analysis alone is insufficient. Gender cannot be considered analytically independent from nationalism or ethno-national identities because competing Tamil and Sinhala nationalist discourses produce particular gender identities and relations. Fraught and cross-cutting relations of gender, nation, class and location shape people's movement, safety and potential for displacement. In the conflict-ridden areas of Sri Lanka's North and East during 19992000 , we set out to examine relations of gender and nation within the context of conflict. Our specific aim in this article is to analyse the ways in which certain identities are performed, on one hand, and subverted through premeditated performances of national identity on the other hand. We examine these processes at three sites-shrines, roads and people's bodies. Each is a strategic site of security/insecurity, depending on one's gender and ethno-national identity, as well as geographical location.
\end{abstract}

\section{Introduction}

This article seeks to provide a feminist analysis of the dynamics of violence in Sri Lanka and to analyse the fraught conjunctures and disjunctures of identity, mobility and security. Shrines, roads and people's bodies, we suggest, become sites of security/insecurity, depending on the confluence of one's national identity, gender and geographical location. We also underscore the case for a more fully feminist analysis of conflict exacerbated by competing, militarised nationalisms, arguing that 'gender analysis' alone does not capture adequately the political processes and geographical articulations of violence, displacement, (im)mobility and security in Sri Lanka. 'Security' is a highly contentious issue in the context of conflict. Whose security is of concern, and to whom? Our focus in this article relates less to the security of the state in the face of secessionist ambitions than to humanitarian understandings of security which prioritise the

Correspondence: Jennifer Hyndman, Department of Geography, Simon Fraser University, 8888 University Drive, Burnaby BC V5A 1S6, Canada. Tel: 604291 5464; Fax: 604291 5841; E-mail: hyndman@sfu.ca 
safety and survival of people displaced by the conflict and the civilian population at large. As Malkki (1995) has argued, human displacement and the deterritorialisation that accompanies it shape the construction of identity and enmity. Debrix (1998, p. 829) warns, however, that 'deterritorialisation cannot simply be understood as an absence of space'. Rather, the widespread and repeated displacement experienced by hundreds of thousands of Sri Lankans, especially Tamils, is a very visceral process of forced migration generated through geopolitical struggles and managed further through technologies of the state that include identification cards and checkpoints along the major roads that connect Sri Lanka's towns and cities.

After a brief discussion of our methods and the specific context of the research, we engage and extend the feminist literature on gender and nation as it relates to conflict. Specifically, we maintain that the deployment of 'gender' as a stand-alone concept by many humanitarian and development agencies assisting displaced people-referred to here as 'gender analysis' -is inadequate. Markers of geographical location and national affiliation shape the very meaning of what it is to be a woman or a man in Sri Lanka and one's security in the context of this conflict. The remainder of the article then traces the production of (im)mobility and (in)visibility at three sites: the Madhu Shrine in Northwestern Sri Lanka; checkpoints along key roads that traverse the country; and people's bodies which are selectively marked by identification cards that seek to fix ethno-national identities. These markings of identity become crucial for the navigation of these checkpoints.

\section{Setting the Stage: methods and political context}

The research on which this article is based was funded by Oxfam Great Britain in Sri Lanka and conducted on an on-going basis over a period of two years, from January 1999 to December 2000 (de Alwis and Hyndman, 2002). Our choice of field sites was based on the desire to capture the variety and complexity of the landscape of conflict in Sri Lanka. War between the Sri Lankan Army and the Tamil Tiger rebels has focused on the northern and eastern parts of the country that the rebels have claimed as part of their homeland, Tamil Eelam. As such, we concentrated on the districts of Trincomalee, Batticaloa and Ampara in the Eastern Province, areas where both government and rebel forces command authority over people, territory and resources; the rebel-controlled Wanni region in the North; and the government-controlled city of Vavuniya, which was the gateway to the Wanni at the time (see Fig. 1$)^{1}$. One should note that the Wanni region was once host to both Tamil and (Tamil-speakin) Muslim groups but since 1990, when the rebels forcibly evicted Muslims from the North to the Puttalam District of Northwest Sri Lanka, the city of Colombo and further afield, it has been inhabited predominantly by Tamils ${ }^{2}$. Due to the security and access issues at the time we could not include Jaffna in the far north, another predominantly Tamil area which was under army control at the time of our fieldwork. The make-up of Eastern Sri Lanka is more mixed, with a population breakdown of roughly one-third Muslim, one-third Tamil and one-third Sinhala. The more highly populated southern provinces of Sri Lanka are predominantly, but by no means exclusively, Sinhala, with significant groups of Sinhala-speaking Muslims and Tamils in Colombo.

Our initial purpose was to analyse the conceptualisation and unfolding of 'gender' in both Sri Lankan and international non-governmental organisations 


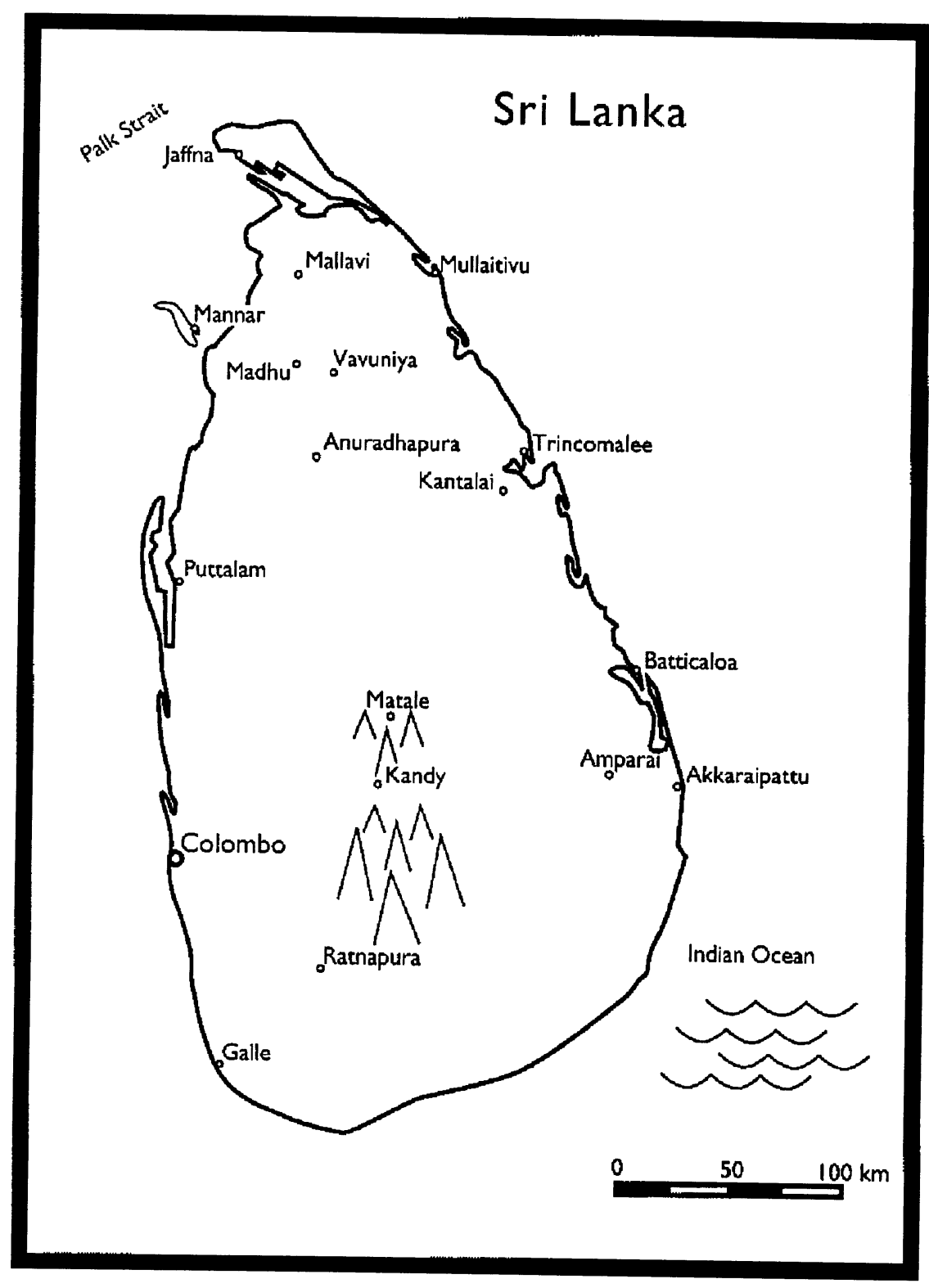

Figure 1. Map of Sri Lanka.

(NGOs) delivering humanitarian and development assistance (Hyndman \& de Alwis, 2003). We also found, however, that mobility and lack thereof emerged as a major issue in this theatre of war, survival and human displacement. The links between gender, nation and mobility thus became part of our inquiry.

As a team of two researchers accompanied by field assistants fluent in Tamil, Sinhala and English, we made two field visits to each of the regions, followed by a third visit to hold several workshops to share our findings and collect feedback from participants in December 2000. Additional field visits and interviews were also conducted individually by the authors throughout the course of the research. 
During the research phase, we jointly conducted 58 interviews with local NGOs, international NGOs and UN agencies in the regions and in the capital, Colombo. In addition to these interviews, we visited 32 projects that were being implemented by NGOs in Mullaitivu, Kilinochchi, Akkarayan, Mallavi, Madhu, Vavuniya, Puttalam, Trincomalee, Nilaveli, Kantale, Batticaloa, Akkaraipattu, Amparai and Kalmunai, where we met with displaced Sri Lankans, or 'beneficiaries' of the NGO projects ${ }^{3}$. In Colombo, we also engaged in extensive library and archival research at these offices.

Our positioning as a bi-national team (a Sri Lankan anthropologist and a Canadian geographer) has proved particularly fruitful, frequently enabling us differential access to people and places. One of us was welcomed more readily into circles of expatriates; the other became the main interlocutor with the senior Sri Lankan staff running many of these organisations. Ironically, only the foreign researcher (as a 'gender consultant' of Oxfam) could safely visit the northern region of the Wanni, controlled by the separatist rebel group, the Liberation Tigers of Tamil Eelam (LTTE). This 'power geometry' highlights the importance of nationality and national identity in terms of access to particular areas (Massey, 1993). It also underscores the unusual phenomenon whereby the category of 'foreigner' is unmarked. At the time the research was conducted, Sri Lankans of all national affiliations were required to obtain passes on a daily basis in the northern district of Vavuniya, so that the army could monitor their presence in the area. Every person was required to register for a daily 'pass' by showing her/his national identity card, a document that implies Sri Lankan citizenship but in practice provides a basis for asymmetrical rights and mobility. No passport registration or passes were required of foreigners. We return to these technologies of mobility later in the article.

\section{Situating Sri Lanka}

A war of competing, militarised nationalisms between the Liberation Tigers of Tamil Eelam and the Government of Sri Lanka's armed forces has been waged for more than 20 years. Mass displacement, multiple displacements, long-term displacement and attacks on communities of displaced people amid intense militarisation across the country present massive challenges to both national and international organisations positioned to address the human needs they generate. The conflict has spawned large-scale displacement within the country and well beyond its borders, where a significant Sri Lankan Tamil diaspora has emerged from this country of 20 million people (Hensman, 1993; Steen, 1993; Fuglerud, 1994, 1999; McDowell, 1996; Daniel, 1997). More than 800000 people were displaced within the borders of Sri Lanka in 2002 (Refugee Council, 2002). The death toll exceeds 60 000. A Ceasefire Agreement between the Government and the LTTE was drawn up in February 2002, and led to the dismantling of military checkpoints that were in existence during our research period (their reinstallation, however, remains a constant possibility given the dynamics of the political situation in Sri Lanka). Major transportation routes to the North and East were also reopened during the post-Ceasefire period. No substantial peace agreement, devolution of power or constitutional reforms, however, have as yet been negotiated between the warring parties ${ }^{4}$.

Sri Lanka's present is an expression of a long history and geography of struggle. Sri Lankan and Sri Lankanist scholars, whose work spans several decades, have 
provided incisive analyses about the contemporary conflict within the country (Abeysekera \& Gunasinghe, 1987; Spencer, 1990; Jeganathan \& Ismail, 1995; Tiruchelvam, 1996). The current iteration of war between the LTTE and the Government of Sri Lanka dates back to at least 1983 when pogroms against Tamils in Colombo led to their murder, the looting of their property and burning of their homes. The pogroms were considered retaliation for the killing of 13 Sri Lankan (Sinhala) soldiers, by the LTTE, on the Jaffna Peninsula.

During the 1999-2000 research period, government-controlled areas were often referred to by those working in them as 'cleared', and LTTE-controlled areas as 'uncleared'. In contrast, on the LTTE side of the line, one referred to the 'unliberated' areas controlled by the Sri Lankan government and army and the 'liberated' zones controlled by the local LTTE authorities. The economic and political differences between these territories were measurable: the LTTE used a different time zone for areas it controlled (with its own armed forces and system of taxation), and these areas were-on the whole-much poorer than the government-controlled lands. These spaces shifted continually as militarised frontlines advanced or were ceded in these so-called 'border areas'. Roads around Nilaveli, a village north of Trincomalee, were controlled by government forces during the day and by LTTE cadres at night. Passing checkpoints on such roads

depended largely on the means of transportation one used. Vehicles marked as belonging to the United Nations or international NGOs were waved on quickly, often not stopped at all. Private cars underwent more scrutiny, but public buses were by far the most carefully checked, pointing to class as a potentially relevant social positioning in determining mobility.

Sri Lanka provides an excellent example of how the distinction between (public) 'battlefield' and (private) 'home front' has virtually ceased to have any meaning in the context of war (Giles \& Hyndman, 2004). During the course of research, 'frontlines' were shifting all the time, depending on the success or failure of various efforts on the part of the Sri Lankan Army (SLA) and the LTTE. As new territory was captured or ceded, a new group of people was invariably displaced. The idea that civilians are out of bounds and that fighting is solely between soldiers was largely irrelevant in this conflict: civilians are often the target of either real or threatened violence. Certain groups of civilians are perceived as a threat to the Sri Lankan state, just as specific politicians are seen as a threat to the formation of a separate Tamil state. Suicide bombings by the LTTE aimed at high profile politicians are not uncommon. Many of these recent bombers have been women. The result is a visceral, embodied warfare fuelled by highly gendered expressions of militarised nationalism. The gendered identity of a Tiger thus cannot be separated from his/her nationalist cause; they are mutually constituted, a point to which we will return.

\section{Querying Gender in Feminist Politics}

Gender is certainly a central concern of feminist analysis and politics, however, its primacy over other social, economic, cultural and political filiations is not fixed across time and place (Hyndman, 2001). Stasiulis (1999, p. 194) elaborates on the importance of relationality, positionality and 'relational positionality' to feminist politics: 'They refer to the multiple relations of power that intersect in complex ways to position individuals and collectivities in shifting and often contradictory locations within geopolitical spaces, historical narratives, and movement politics.' 
Recognising the multiplicity of power relations that situate individuals and groups within a context of conflict is crucial: one is never just a woman, but is always a woman from somewhere who may belong to or identify with particular social, cultural, and/or political groups. This point may be self-evident in current feminist scholarship, but not among the humanitarian and development organisations we studied ${ }^{5}$. Our research provided constant reminders that the ubiquitous unmarked category 'woman' in humanitarian and development discourse was virtually meaningless in Sri Lanka without understanding the intersections among gender, geographical location and ethno-national affiliation ${ }^{6}$.

Stasiulus maintains that ' $[c]$ entral to my interpretation of relational positionality is also a rejection of postructuralist deconstructions that deny the material bases for power relations, however complicated their discursive representations' (1999, p. 196). At this juncture we part ways with Stasiulus, arguing that poststructuralist analyses do not categorically deny the material bases of power relations (Hyndman \& de Alwis, 2003). A poststructuralist analysis can reveal the very processes by which particular constellations of power are effaced or naturalised (Butler, 1992). Pratt (2004) also challenges the idea that poststructuralist theories immobilise feminism, noting that they urge us toward concrete rather than metaphysical analyses:

Whether feminism as a social movement is successful in articulating other liberation struggles within the category, woman, is something that is decided through political struggle and not only or finally through philosophical debate....we would expect the feminist movement to be increasingly emptied of its singular focus on woman, and possibly rethought around a broader critique of the production of social difference and the multiple exclusions enacted by dominant groups and institutions (Pratt, 2004:84).

We maintain that a fully feminist approach to understanding gender identities and relations in the context of humanitarian crises focuses upon the production of social and political differences and the exclusions enacted by the state in relation to minority groups (Hyndman, 2003; Hyndman \& de Alwis, 2003). Gender identities and relations constitute a key dimension of people's social and geographical locations, but in humanitarian discourse they tend to be extracted selectively and separated from the larger nexus of political, social, cultural and economic relations of power that shape one's mobility, security and potential for displacement. In Sri Lanka, what it means to be a woman in different regions of Sri Lanka is infused by differences in class, caste and nation. In the east coast towns of Batticaloa or Akkaraipattu, for example, mobility and employment opportunities for Tamil women are markedly different than those for Muslim women, who are expected to work (for pay or not) within the confines of their family home. The mobility of Muslim women varies dramatically from that of Tamil women of the same social class, and they are assigned different spaces of acceptability. Hence, there is no single approach applicable to 'women' in the Eastern Province.

Men and women are affected differently by war, just as they are affected differently by the antidotes, services and interventions that are made in the name of humanitarian assistance. While it may be true that women (everywhere) are systematically worse off than men (economically, politically, socially), women from the majority (Sinhala) ethnic group and/or from the middle and upper classes certainly enjoy less vulnerability to displacement and more mobility, on 
average, than men from a minority ethnic group, especially those from the working classes or peasantry. Extant hierarchies of power that include control over land, official language ability and religious affiliation produce specific gender relations depending on one's location within the hierarchy (Hyndman \& de Alwis, 2003). In the following section, we move to a discussion of gender and nation, arguing that gender cannot be separated out from historical and geographical contingencies of ethno-national affiliation and the rise of nationalism as it relates to conflict in Sri Lanka.

\section{Gendering Nationalism in Sri Lanka}

In Sri Lanka and elsewhere, one's affiliation with a particular ethno-national group may be articulated differentially through gender identities. Over the past few decades, feminists in many countries have produced an extensive literature that examines and analyses the links between gender and nation, often contextualising such relations within postcolonial societies. A great deal of research on nationalism has focused on the role of gender in the construction and reproduction of ethno-nationalist ideologies (for some pioneering texts, see Jayawardena, 1986; Anthias \& Yuval-Davis, 1986; Chatterjee, 1986). The mutually constitutive identities of gender and nation position women and men in particular ways, rendering women, for example, as the bearers of 'tradition' and national culture, and men as the protectors of the faith or nation and its property [women] (Chatterjee, 1989). As Chatterjee (1996) notes, nationalism is a project of asserting difference through internal unity, but one within which hierarchies of gender, race, class, and caste are hardly unifying. Jayawardena and de Alwis (1996, p. xiii) note further that 'ultra-nationalist movements have used women as cultural representatives and constructed them in relation to western domination. Women are the carriers of 'authenticity'; this puts them in a difficult position vis-à-vis their gender and religious identities.' The Subaltern School of historians in India (and those they have inspired) as well as feminist scholars in various parts of South Asia have played a central role in this endeavour of writing back, of producing their own knowledge of place and history and decolonising (neo)colonial epistemologies of knowledge production (for a sampling see Guha, 1981; Chatterjee, 1986; Sangari \& Vaid, 1989; Hasan, 1994; Jeganathan \& Ismail, 1995; Jayawardena \& de Alwis, 1996).

While nationalism may seek to homogenise differences through the unifying discourses of nationhood, it none the less generates contradictory positions for women as symbols of cultural purity, agents of resistance against western domination, and 'role models for the new nationalist patriarchal family' (Moghadam, 1994, p. 4). Nationalism is not a fixed notion, nor can it claim a unitary subject that bears national affiliation separate from gender, caste, class, and religious identities. The construction of national identity and gendered nationalism in Sri Lanka has been traced and debated by a number of scholars (Jayawardena, 1986, 1993, 1995; Hellman-Rajanayagam, 1990; de Alwis, 1994, 1996; Ismail, 1995; Maunaguru, 1995; Jeganathan, 1997). These analyses highlight the intersection of gender with nationalism and their connections to state-building in Sri Lanka. Sri Lankan women, be they Sinhala, Tamil or Muslim, continue to be constructed as the reproducers, nurturers and disseminators of 'tradition', 'culture', 'community' and 'nation'. Such perceptions have not only legitimised the surveillance and disciplining of women's bodies and minds in the name of 
communal/national 'morality' and 'honour' but they have also re-inscribed the expectation that whatever women may do, they are primarily mothers and wives-they have to marry and have children and the domestic burdens are solely theirs.

The political mobilisation of 'motherhood' through Mothers' Fronts during the 1980s and 1990s has been a counter to violence, both in the context of the war in Sri Lanka's North and East as well as the second JVP (Janatha Vimukthi Peramuna/ People's Liberation Front) youth uprising in the South. The seemingly unquestionable authenticity of these women's grief and espousal of 'traditional' family values has provided these Mothers' Fronts with an important space for protest at a time when feminist and human rights activists who were critical of either state or JVP violence were being killed with impunity ${ }^{7}$.

While women have been the victims and survivors of violence, they have also been its perpetrators. Although some women participated in both JVP youth insurrections, the issue of women militants has really come to the forefront in the 1990s with the increased participation of Tamil women militants in combat. In fact, the women's wing of the LTTE-Suthanthirap Paravaikal (Birds of Freedom)-has acquired almost as much notoriety as their male counterparts since a female suicide bomber killed Rajiv Gandhi, the Prime Minister of India, in 1991. The increased visibility of these women in recent LTTE campaigns against the Sri Lankan forces has also generated much discussion among feminists in Sri Lanka on the role of female militants in anti-state movements, a familiar question to those who have studied the positioning of female fighters in guerrilla groups.

Much of this feminist debate is framed in binary terms of whether the women in the LTTE are liberated or subjugated (de Silva, 1994; Coomaraswamy, 1996), agents or victims (de Mel, 1998). Such exclusivist categories of either/or, us and them tend to obscure the fraught and multiple locations of women in the context of war (Maunaguru, 1995; Cockburn, 2000). An intensified examination of the coconstitutive relationship between places and identities, and a move away from the extremes of dualistic metaphors and binary thinking (Pratt, 1998) provide a strong analytical base for understanding the gendered politics and practices of militarised nationalisms.

\section{Shrines, Roads, Bodies: constituting peoples and places}

We contend that the construction of certain spaces as safe and others as dangerous is a key part of geopolitical discourse in Sri Lanka. One space deemed dangerous was referred to repeatedly as the source of suicide bombers, namely Batticaloa on the eastern coast of Sri Lanka. The act of reiterating this danger and of enacting rigid security checks on people exiting the area contributed to the construction of 'terrorist' space. The idea that Batticaloa is an LTTE stronghold that produces suicide bombers was one that was promulgated and practiced by government soldiers on a daily basis at the checkpoints into and out of Batticaloa.

In contrast, the Madhu Shrine, in Northwestern Sri Lanka, was designated an Open Relief Centre by the United Nations High Commissioner for Refugees (UNHCR) and as such was an internationally sanctioned safe space. The Sri Lankan government also established 'Welfare Centres' for people displaced by the war, particularly in the Vavuniya and Trincomalee Districts ${ }^{8}$. Very basic necessities were provided in these centres during our visits in 2000. Occupants were arguably better off with the assistance than without; however, they were 


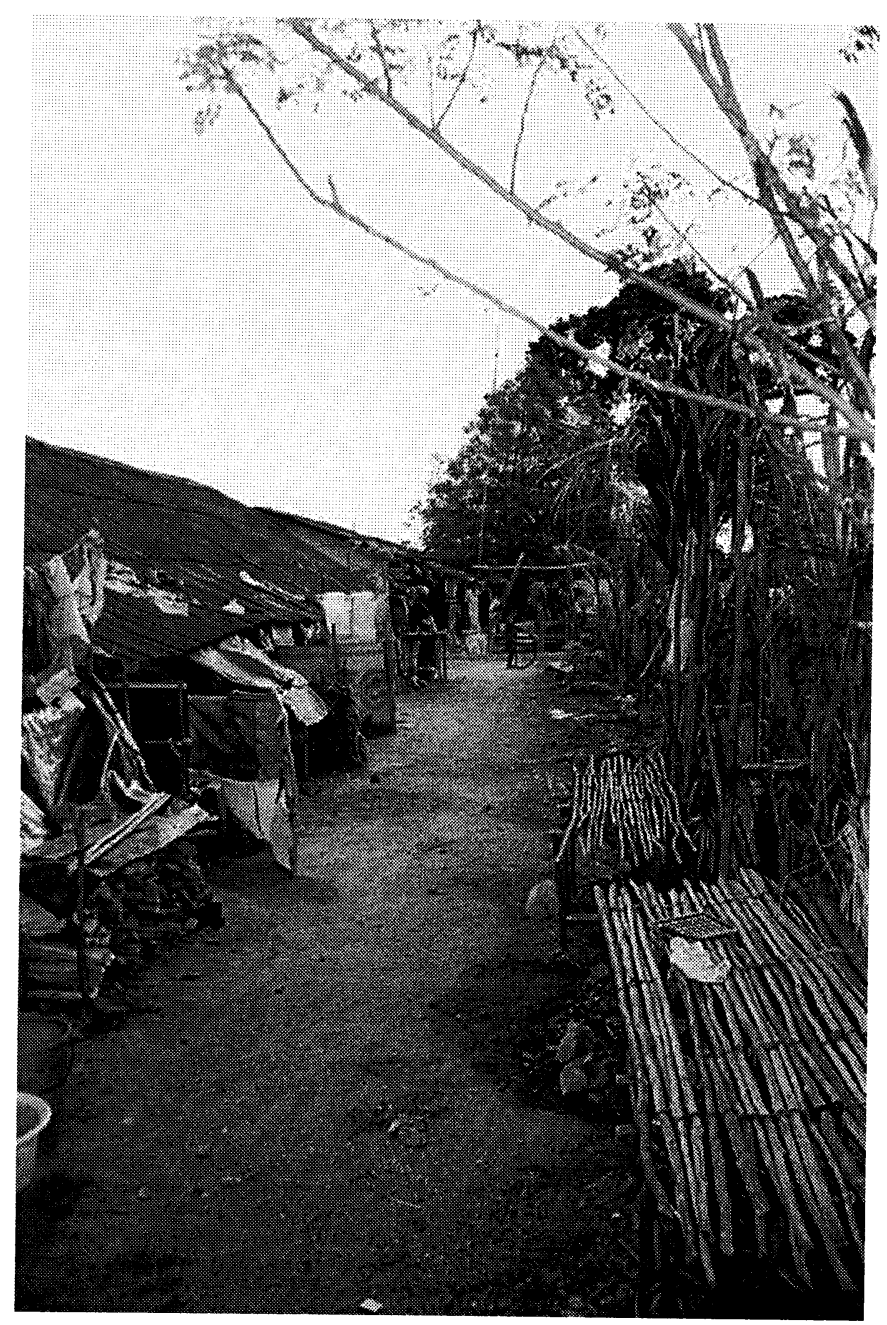

Figure 2. Government-run welfare centre, Vavuniya.

viewed tacitly by the government as a potential security threat, so their concentration in the centres may have other geopolitical meanings. In June 2000, some 25000 displaced people occupied 17 Welfare Centres in Vavuniya District. For these occupants, the centres were anything but safe when the LTTE released a public injunction that all civilians should leave the area for their own safety; the implication was the LTTE was planning an attack of the area. The displaced people who resided in these Centres were prohibited from leaving by government authorities, and waited in fear to see if the LTTE would indeed take Vavuniya city and/or harm them. Fortunately, they did not. Even in contexts where an attack by the LTTE might be less imminent, the Welfare Centres remain sites of great anxiety and tension as they are easily accessible to other Tamil militant groups, now working in tandem with the Sri Lankan government, who use them as recruiting grounds (Fig. 2).

Displacement and deterritorialisation shape the social construction of 'nationness', history, identity, and enmity (Malkki, 1995). Given our interest in particular 
sites of displacement, we would add that such processes also constitute place. Doreen Massey's work has been especially useful in shattering the binary between space and place that poses one as a site of interaction and the other as enclosure (Massey, 1991, 1993). While she notes rightly that there are no pure or essential places, her analysis tends to cast places and spaces solely as products of human interaction, and thus misses Lefebvre's (1991) insight regarding the coconstitutive nature of spaces and people. We find such a problematisation of space and place especially useful to analysing the accounts of displaced people generally. Malkki's study examines differential processes of identity formation among Burundian refugees in rural and urban locations in Tanzania, rooting them in the socio-political effects of the refugee camps as a technology of power (Malkki, 1995, p. 52). While her focus is on the production of a national order of things in which refugees tend to be liminal, our focus is on the production of orderliness within a nation-state during conflict, in which displaced people are replaced at the margins of this landscape. To be more precise, our 'object of inquiry' is not displaced people per se, but the administrative practices and technologies of power that position displaced people in particular places and with specific identities (see also Hyndman, 2000). We move now to the ways in which processes of displacement and deterritorialisation inscribe particular places situated within Sri Lankan war zones.

\section{Madhu Shrine}

Why was a famous Catholic shrine chosen by UN authorities as a site of sanctuary for displaced people on the frontlines of a war zone? And from a feminist perspective, why is such a camp worthy of our attention? Feminists in political science have long questioned understandings of security that privilege state sovereignty and security ahead of more embodied and material understandings of security (Peterson, 1992, 1996). '[M] uch IR writing remains disembodied. The writers and their subjects do not have (visible) bodies' (Pettman, 1997, p. 95). Feminist and poststructuralist readings of geopolitics question not only the epistemological stakes, but also the dominant categories of security studies. J. Anne Tickner notes that feminists within the field of international relations define security more broadly, 'as the diminution of all forms of violence, including physical, structural and ecological' (2001, p. 62). While we find this definition politically compelling, it is too broad to be workable in the context of a conflict zone. We argue instead for a narrower definition that foregrounds freedom from violence and freedom from fear of violence as of primary concern in the Sri Lanka context. Security, in this sense, is a central issue for feminist politics.

Madhu is a tiny town in Northwestern Sri Lanka (in the Mannar District and the southern part of the Wanni) famous for its shrine (Fig. 3) that has attracted Catholic pilgrims of Tamil and Sinhala descent from all over Sri Lanka and other parts of the world. In 1990 it adopted yet another identity when UNHCR established an Open Relief Centre (ORC) at Madhu. The ORC was declared a 'zone of peace' by UNHCR, but was administered officially by the church under UNHCR's supervision (Jeyaraj, 1999). The zone of peace provided temporary sanctuary from the war and access to basic necessities, such as housing materials, food and water. When founded, the church and shrine were located in LTTEcontrolled territory. Agreements were made with the LTTE that the shrine area would remain demilitarised at all times; no arms would be carried and no combat 


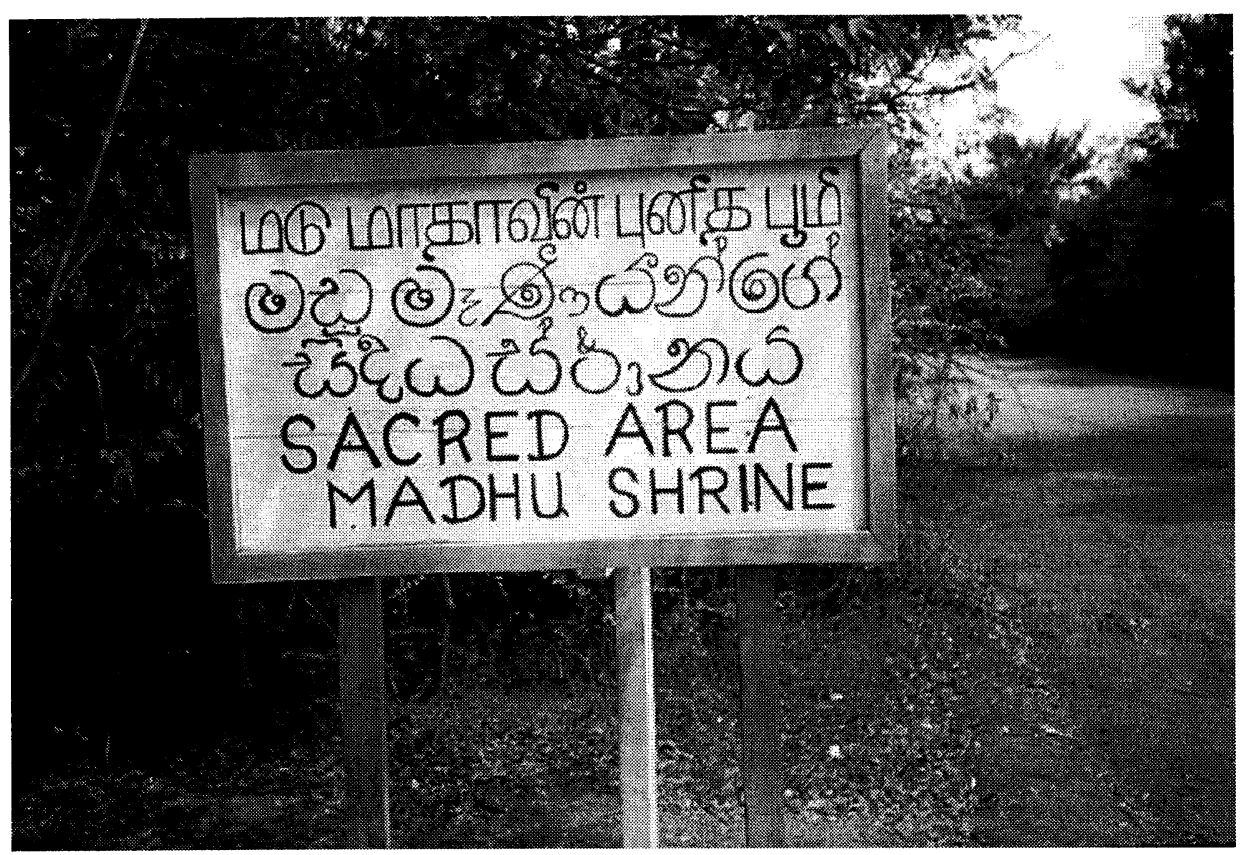

Figure 3. Sign marking Madhu Open Relief Centre (ORC).

fatigues were to be worn. Unlike Bosnia or Somalia, the Open Relief Centre at Madhu was politically neutral, completely demilitarised, and without international troops to enforce peace. It was further distinguished from welfare centres in Sri Lanka that hosted displaced people by its long history and well-known reputation as a safe place before the war began and UNHCR arrived (Hyndman, 2003).

The Catholic shrine and church at Madhu is the most sacred in the country (Perera, 1998). In 1544, Catholic converts from Mannar Island went to the Madhu area, fleeing the lethal power of a Hindu king in Jaffna who had massacred some 600 Catholics. Only a small group who escaped with a wooden statue of the Virgin Mary made it safely to Madhu. In the eyes of the survivors, the statue-imbued with many meanings that are both gendered and derived from the colonial encounter-had saved their lives. They erected a church at Madhu, which has become a sacred site of pilgrimage for Catholics of all ethnic backgrounds ever since. When UNHCR arrived in Madhu and established a 'zone of peace,' it did so with a tradition of 450 years of sanctuary behind it.

In 1999 Madhu was 'cleared' by the government in two senses of the word: first, the Sri Lankan Army took control of the territory, ostensibly from the LTTE, although Madhu had been a sanctuary from both SLA soldiers and LTTE rebels; and secondly, government forces emptied the camp of thousands of displaced people during the month of May 1999, breaching the 'no guns, no uniforms' agreement. In November 1999 fighting in the area heightened, and more than 3500 people sought refuge again in Madhu, but the shrine ceased to be safe by all accounts. It became the target of both LTTE and army shelling, killing more than 35 civilians. The LTTE regained control of the area, and by our second year of research in the area-during June and July 2000-Madhu was once again full of 


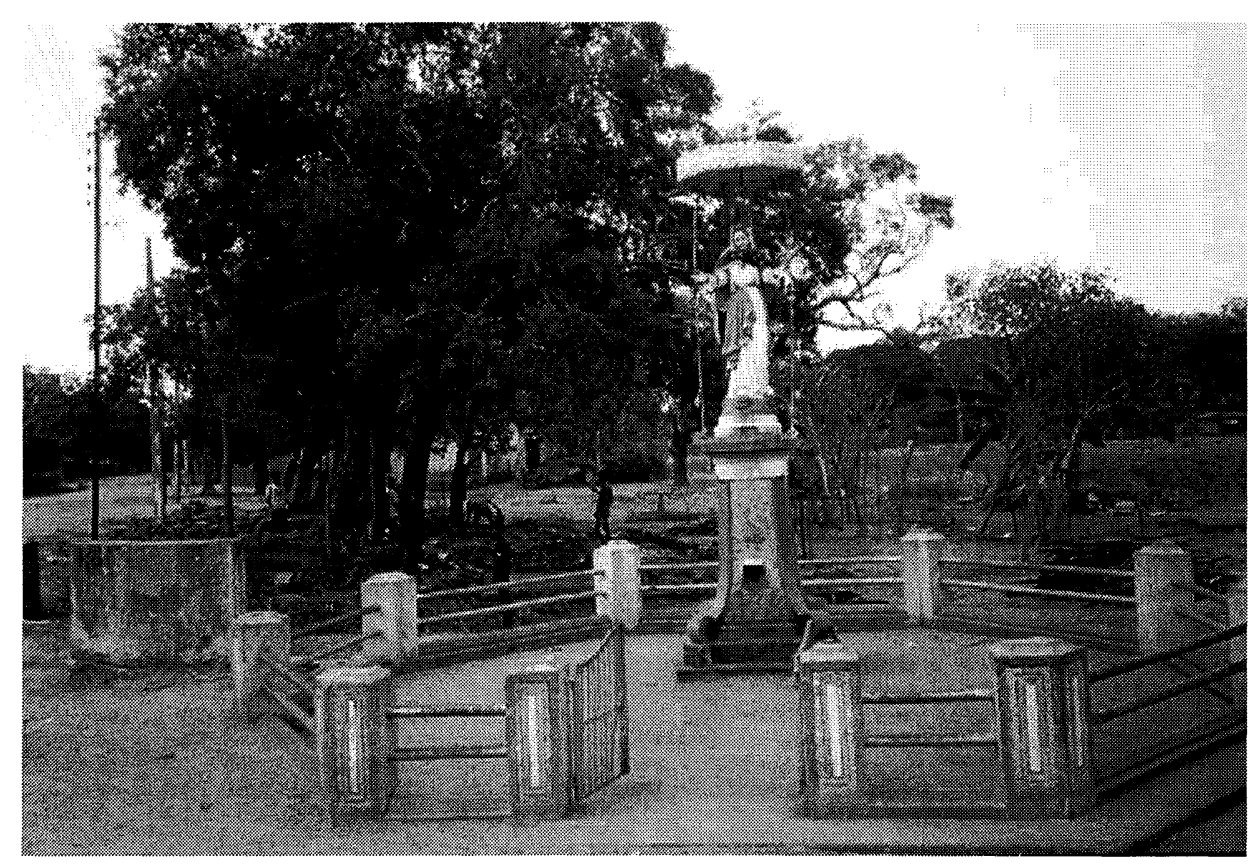

Figure 4. Statue of the Virgin Mary outside Madhu Shrine.

displaced people. These changes illustrate the radical shifts generating displacement in the North, especially in areas close to the 'frontlines' (Fig. 4).

The economic and political implications for displaced people living in Madhu vary depending on which side of the 'line' the shrine is located. When living in LTTE-controlled territory, access to goods is very difficult due to the embargo from the South. However, mobility within the LTTE-controlled area is quite free, and many households in Madhu have one or more family members who participate in fishing, agriculture, or day labour for wages, creating some degree of self-sufficiency. In contrast, when Madhu was taken over by the Sri Lankan Army for a spell in March of 1999, scarcity of goods disappeared and all kinds of banned products became available. Ironically, however, the jobs that people in Madhu had accessed in LTTE-controlled areas were now off limits, separating them from the livelihoods they had established, and making the purchase of the now widely available goods difficult ${ }^{9}$. Several thousand displaced people lived in Madhu, albeit with significant population fluctuations throughout the research period. While insecurity prevailed, residents generated some economic stability and household security through a spatialised insurance strategy in which many kept one foot in Madhu's Open Relief Centre and the other in the local economy in which they normally participated. This strategy was a highly gendered one in which women and children tended to reside in Madhu, while male family members travelled to work elsewhere in Mannar district, engaging in day labour or working on their own plots of land. While certainly not ideal, this gendered dynamic of 'mobile displacement' was more sustainable than the dependent livelihoods of displaced people in the nearby Welfare Centres of Vavuniya. Mobility in and out of the Vavuniya Welfare Centres and Vavuniya townsite during this time was constrained and carefully policed making it less possible to 
find work or any educational opportunities beyond. Displaced people residing in the government-run Centres received a meagre monetary allowance of 35 rupees per day per adult (about US $\$ 0.35$ per person; each child received 20 rupees or $\$ 0.20$ per person) that is barely adequate to meet basic needs on a daily basis, leading to widespread indebtedness and despair.

Pass restrictions to travel outside Vavuniya serve to contain this population even further, and to construct Vavuniya as another potential 'hot spot' because of the large number of displaced Tamils. Extrapolating Malkki's argument about identity formation among refugees as place-based, we would expect the identities of displaced people in Madhu to be very distinct from those in Vavuniya, that the 'processual constitution' of people's identities at each site would be quite different (Malkki, 1995, p. 52). Our research did not explore explicitly identity formation among these two groups, but what information we did glean points to more sustainable livelihoods where mobility is greatest. In Madhu, mobility has been largely unimpeded within the LTTE-controlled area until the Sri Lankan army captured the area in 1999. In Vavuniya, subjects were treated largely as beneficiaries of the state, but with strict limitations on their mobility and livelihoods.

\section{Roads}

Roads have a long history as 'vectors of capital' (Jeganathan, 1997, p. 222). In times of war they also become sites of conflict, mobility, military/militant strategising and logistical access. Within refugee camps, roads prove to be both vital logistical and security links. While the needs and movements of refugees are often cited as key factors in the planning of humanitarian assistance in camps (UNHCR, 1990, 1991), security and logistical considerations in planning often prevail with highly gendered implications for the workload and daily routines of refugees (Hyndman, 2000). Military tactics also depend upon proximity to passable roads. In Sri Lanka, roads are strategic access routes for warring parties, but also the location of checkpoints that control the entrances and exits of civilians based on readings of gender and national identity.

During 1999-2000, the Government of Sri Lanka and its military relied heavily on road access to the Wanni as a supply route to deliver weekly food rations to displaced people there (Fig. 5). The government made a remarkable effort to get this food to people living in LTTE-controlled areas, even though the LTTE often controlled people's access to this food once it crossed the 'border' into the North. Supplying food rations along these routes, especially the north-south Mankulam road (Highway A9), was important for two reasons: (1) the state appears to be assisting and protecting its citizens during a crisis, regardless of which side of the line they are on, their location, or ethnicity; and (2) supplying food rations is a very material and geopolitical assertion of sovereignty. In the first case, the Sri Lankan Government aimed to demonstrate its commitment to all displaced people, so that in the eyes of the displaced and other (possibly donor) governments, it could be seen to be fulfilling its obligations to its citizens.

Roads also represent 'grey zones' in the colourful vocabulary of the war in Sri Lanka. Grey zones can demarcate spaces controlled by the Sri Lankan Army by day and the LTTE by night. For example, in Nilaveli, an area just north of Trincomalee town, Sri Lankan army soldiers check documents and patrol the main road. At dusk they return to base and the road is under rebel command. 


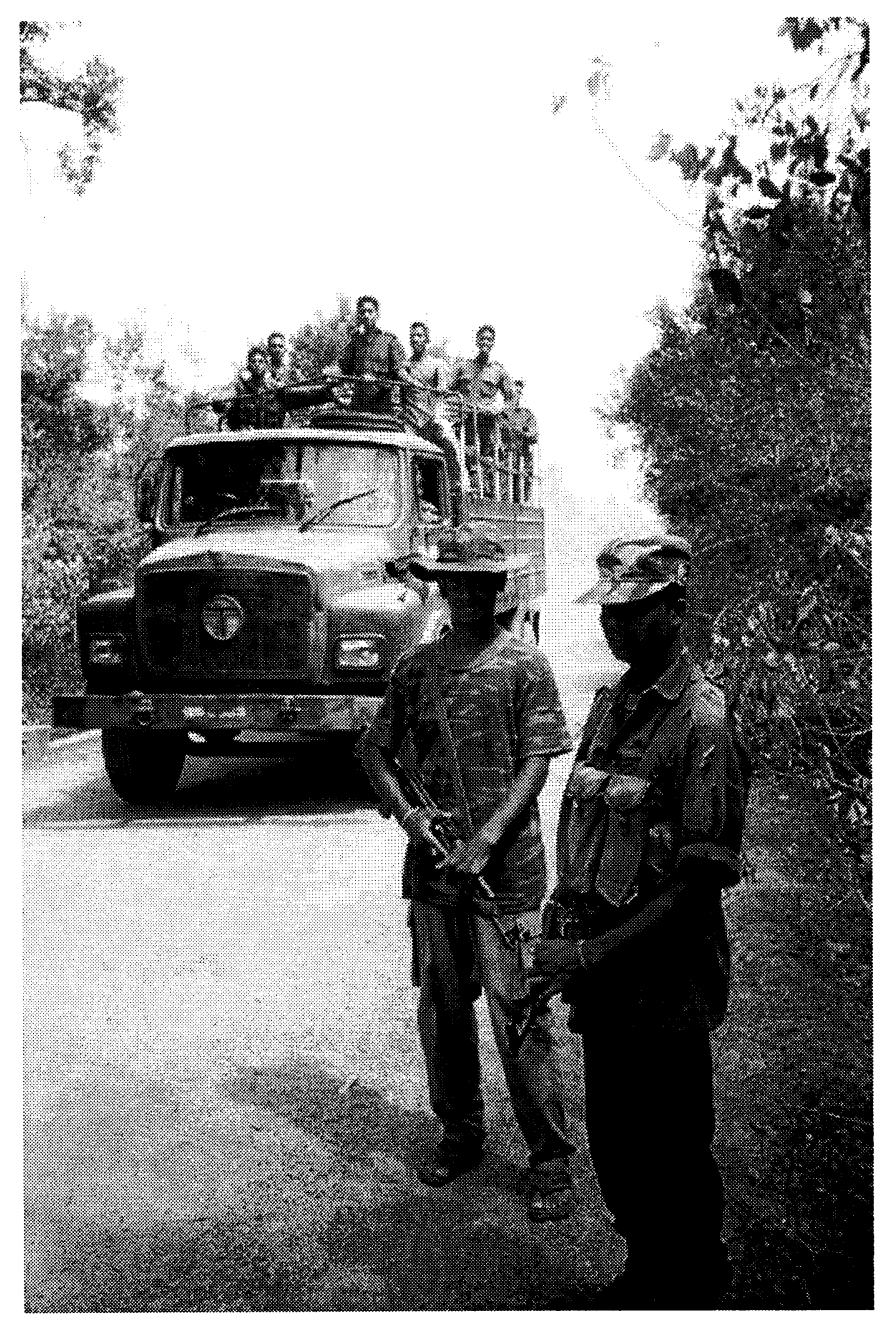

Figure 5. Army troops on the Vavuniya-Madhu Road.

Similarly, a given road may change hands from month to month; the VavuniyaMadhu road was controlled by the LTTE throughout most of our study period, but for a brief window of time the Sri Lankan Army patrolled this access route.

Where roads mark the separation of government and Tigers' spaces, the safety of civilians is always at risk. We collected reports of women who were raped on one side of the 'line' by perpetrators who then returned to the other side to escape detection and conviction for their crimes. There were literally two economies of accountability and justice at work, sometimes within a given town. Roads most often marked the boundary between the two. Since the Ceasefire Agreement, grey zones have in some respects become more 'black' and 'white'. The LTTE began collecting taxes from people in its envisaged 'autonomous area', including Batticaloa and Amparai, even though the Ceasefire Agreement, the Constitution of Sri Lanka, and Parliament have authorized no such powers (Perera, 2003).

These grey zones can also be ascribed meanings of neutrality, whereby they become 'safety zones' or 'a demilitarised no-man's land', a notionally feminised 
space of relative peace in between the zones of conflict controlled by warring parties. In May 1999, a key supply route for food rations to the Wanni region was closed and a military offensive launched by the government. By July, the rebels said that over half a million Tamils in the Wanni faced starvation (Reuters, 1999). The Sri Lankan military proposed that the LTTE retreat five kilometres along the Mankulam road to create a demilitarised safety zone. The LTTE agreed in principle with the idea, but offered to retreat only 250 metres, as it did not want to risk ceding the five kilometres the military proposed. In the end, no agreement was reached. Such politics illustrate the tenacity of both sides to protect their territory, despite ever-changing boundaries, and to control people's passage across these borders.

Nowhere has checkpoint culture become more developed than in Sri Lanka. Throughout the Northern and Eastern Provinces in 1999-2000, on the main roads leading to and from these Provinces (to a lesser extent on all the other main roads that crisscross the country), and in the capital, Colombo, concrete-filled oil drums painted in camouflage colours and spiked steel grates were used to form road blocks and safeguard possible 'targets' ${ }^{10}$. The checkpoint, as Jeganathan has argued, is constituted by the 'anticipation of violence' (2002, p. 360).

Searches at checkpoints are a routine, labour-intensive, time-consuming inconvenience for many, and a constant threat full of fear for those marked as 'dangerous' by the state. As Jeganathan has noted, such a marking is produced through the checker's attempt at securing the checked person's political identity'are you an enemy of the state and does your enmity extend to violence upon its citizens?', which is in turn premised upon a reading of the checked person's social/cultural identity (Jeganathan, 2000, p. 362). Enmity is based on socially produced markers of identity that are fixed by the government-issued identification card.

For those who travel by bus, travel times can easily treble because of numerous checks of each individual. As discussed below, the process of checking is a gendered one that makes various assumptions about birthplace, current home address, and ethnicity that determine who constitutes a 'security risk'. Increasingly, women soldiers of largely Sinhala descent have been assigned to checkpoint duties. We also observed that police forces had been assigned military duties, such as operating the checkpoints, making civilian law and order often indistinguishable from the armed defense of the nation-state.

\section{Bodies}

People's bodies are perhaps the finest scale of political space. Bodies are the sites at which gender and national identity may be marked in Sri Lanka and performed in particular ways. Although critics from a range of disciplines have suggested that social identity is constituted by a series of performances, most have focused on the production of gendered, sexualised and racialised identities. Butler's (1993) pathbreaking formulation of 'performativity' argues that subjectivity is enacted through reiterative performances over time: 'displacement is that which is excluded or marginalised by the construction of a subject position' (p. 155). For Butler, these practices cannot 'be a human act or expression, a willful appropriation, and it is certainly not a question of taking on a mask; it is the matrix through which all willing first becomes possible, its enabling cultural condition' (1993, p. 7). More simply put, Butler underplays any emphasis on people's individual 
agency, arguing instead that our behaviours are part of 'regulatory fictions' that are pre-scripted to some degree, although not prescribed. To the extent that government identification cards may be considered technologies of the state that attempt to fix identity, they may also shape the regulatory fictions Butler proposes.

A very distinct and contrasting view of performance as a dramaturgical metaphor has been part of sociological discourse for many decades, primarily through the contributions of Erving Goffman. In The Presentation of Self in Everyday Life (1959), Goffman contends that a complex system of theatrical performances is enacted by intentional agents in order to function in a given social context. He proposes a view of the individual as a series of performance masks hiding a manipulative, strategic self who reveals only what $s /$ he wants her/his audience to see. Particular masks or performances are enacted in public spaces, whereas these are removed in private domains. The separation of public and private spaces have obvious limitations, especially for feminists who have long challenged this divide, but Goffman's metaphor is useful in some aspects to understand the practices adopted by certain groups of people at checkpoints in Sri Lanka.

People actively construct their identities in ways that will reduce harassment and threats-either perceived or real. Every Sri Lankan is required to carry a national identity card that records name, sex, date and place of birth, occupation and home address. Changing one's home address on one's ID card is an arduous bureaucratic ordeal that frequently invokes suspicion, especially if one is a Tamil, and is thus rarely embarked upon. The handwritten features of these records are in either Sinhala or Tamil script, both official languages of the state. These recordings can be important as they may signify location through language used, fixing one's social/cultural identity. For example, a card written in Tamil is more likely to have originated in the north or east of the country where administrative affairs are conducted in Tamil than in Colombo, where one may 'be' Tamil but one's ID card will be written in the hegemonic language, Sinhala (cf. Jeganathan, 2002, pp. 362-363).

Place of birth and family name also serve to fix identities in ways that can, in turn, be interpreted in specific ways by police and military authorities. One Tamil man we interviewed carries only his Sri Lankan passport and his driver's license in order to avoid the harassment he has experienced when carrying his national identity card $^{11}$. His passport marks him as Sri Lankan and his driver's licence notes his current address in Badulla, a predominantly Sinhala town in southeast Sri Lanka, but neither document necessarily marks him as Tamil. Both documents could mark class position, but this is much more ambiguous. People from a range of class backgrounds have passports to travel abroad, but some go to work in the Middle East or Singapore as drivers or maids. A driver's licence might be held by the owner of a car or by her/his driver. Class appears to be indicated in this man's dress and speech. None the less, both class and location are performed in particular ways, and Tamil ethnicity/nation is downplayed at all costs ${ }^{12}$.

Identity can thus be fixed to some extent through the interpretation of documents produced by the state that allows certain kinds of surveillance. Appadurai (1996) explores colonial systems of counting bodies and the impact of these classificatory regimes (cf. Cohn, 1987). In the context of early twentieth century India, a communitarian approach to representing the 'body politic' resulted in separate electorates for Hindus and Muslims. It was 'crucial in defining the dynamics of ideas of majority and minority as culturally coded terms 
for dominant and disenfranchaised groups in South India' (pp. 130-131). Similarly, the experience of colonialism in Sri Lanka has privileged certain national groups over others in terms of education, ruling relations, and access to capital (Jayawardena, 2002).

Identity documents can also be subverted by those marked in ways that disadvantage them. Geographical ignorance of Tamil-dominated parts of the country on the part of those who 'man' and 'woman' the checkpoints can be an important advantage for people who come from these areas. One woman we interviewed came from a town on the Jaffna Penninsula, known for its famous Buddhist temple. This was, she recounted, helpful in creating ambiguity around her ethnicity, augmented by the fact that her first name is also common among Sinhala Sri Lankans. Having been raised by an aunt in Colombo as a young girl, she was fairly fluent in spoken Sinhala, so that at most checkpoints she could 'pass' without harassment and lengthy questioning. Similarly, a young man recounted another such story. He was born in the small town of Mulai, close to the city of Jaffna, otherwise unknown except for the large hospital situated there. For most soldiers that he encountered at checkpoints, Mulai could have been anywhere in Sri Lanka so he too was able to pass as Sinhala, given his trilingualism ${ }^{13}$. So while one's place of birth cannot be altered on one's identity card, which like one's family name not only tends to fix one's geographical location but one's ethno-national affiliation as well, there are exceptions to this rule. Geographical location is also constructed in particular ways in the (dominant) national imagination. During 1999-2000 the town of Batticaloa, on Sri Lanka's east coast, was a very grey, 'hot zone' in the context of the war, where the army controlled the checkpoints and ostensibly the streets, and the LTTE controlled other activities. The town hosts a university and many displaced people from Jaffna who did not go abroad or settle in Colombo. One of the most active and progressive feminist organisations, Suriya Women's Development Centre, is also located here. Batticaloa is also a place of remarkable violence, where buses full of government soldiers have been blown up, members of parliament have been assassinated, and grenades are exploded on a regular basis.

Batticaloa has been certainly a central site of conflict and violence between the warring factions, but from Colombo it is also constructed as the primary source of 'terrorism', embodied in the LTTE suicide bombers from the area who infiltrate the capital and murder in their wake. Consequently, at the time of our research, military authorities prohibited the use of motorcycle helmets by civilians in Batticaloa town on the presumption that they might be hiding a 'terrorist'. Leaving Batticaloa is an ordeal for all except staff of the international NGOs, and foreigners, who are sometimes exempt from the body searches and vehicle inspections that are routine practice. One Sri Lankan consultant reported having her breasts squeezed several times by a female soldier at the checkpoint, noting that there seemed to be some question of authenticity (suicide bombers generally strap explosives on their bodies). A great number of suicide bombers are women, as they are seen to have an easier time 'passing' as civilians at these checkpoints. The consultant noted that if she dressed as a foreigner or as 'someone from Colombo', in jeans and shirt and carrying a backpack, the authorities at the checkpoints usually left her alone. Again, we return to the idea that identity is enacted through regulatory regimes that expect certain performances from specific people. Behaving in a way that is consistent with being a foreigner or an 
upper-class city dweller defines one, therefore, as a foreigner or upper class city dweller.

Trying to 'pass' as a member of the dominant social group is nothing new for many Tamils who have lived through a long chronology of anti-Tamil riots, in the shadow of violence (Jeganathan, 1998). As one survivor of the riots of July 1983 noted, she now avoids wearing a pottu (an auspicious mark on the forehead that would identify her as Tamil) and has encouraged her children to identify themselves more and more with the majority, Sinhala community even to the point of stressing that they 'marry people from any ethnic community but the Tamil' (quoted in Kanapathipillai, 1990, p. 328). This suggests a distinct but related understanding of performance akin to that of Goffman; in Sri Lanka, the calculated presentation of self in everyday life can be crucial to one's survival. Jeganathan (1998) has most insightfully described such presentations of self as 'tactics of anticipation': 'There is, in the shadow of violence, a repertoire of signifying practices that is positioned in relation to that shadow, that are centrally about "Tamilness"...To live as a Tamil, then, is to learn such a repertoire of tactics' (pp. 98-100) ${ }^{14}$.

One man we interviewed talked about the premeditated ways in which he and his wife, both Tamil, planned their checkpoint crossings. His wife would drive and he would sit in the passenger seat holding their youngest child. This iconography of the middle-class family was helpful, he found. When it came time to show identification, his wife, a physician in the south of Sri Lanka, would first show her documents identifying her as a doctor. Without exception, the authorities at the checkpoint would not request any further identification and would wave the family on. Her credentials as a physician from a predominantly Sinhala area were sufficient to pass. This same family has two daughters who are named ambiguously, so as not to easily identify them as Tamil or Sinhala.

The mobility we enjoyed as researchers in transport provided to us by OXFAM was, in contrast, unfettered. Marked with white flags and recognised as an international NGO at all checkpoints, we sailed through stops that often took those on buses an hour or more. Local staff at the World University Services of Canada (WUSC) office in Vavuniya explained to us that they preferred to travel by WUSC vehicle, rather than by office motorbike, simply because they were more recognised and legitimised by their WUSC affiliation while in the vehicle. In short, they (a predominantly Tamil staff) were less likely to be harassed by (predominantly Sinhala) army soldiers at checkpoints.

Malkki (1995) found that refugees from Burundi who lived in isolated camps identified as exiles whereas refugees from the same exodus who settled in a nearby town were more likely to identify with the people and place of the town. Malkki calls this a 'pragmatics of identity' (p. 153), but it speaks forcefully to the differential production of social relations and identity through distinct spaces. In Sri Lanka the political landscape is quite different, but the pragmatics of identity persists, and is expressed in another way. While the Sri Lankan government attempts to fix identity on individual bodies through the insistence on the carrying of identity cards at all times and their constant checking at checkpoints, people enact specific dimensions of identity in ways that enable them to pass both in terms of identity and related mobility. Their bodies may be marked in seemingly unalterable ways, but gender, social class and occupational status can alter the ways they are read as they travel along Sri Lanka's roads. 


\section{Conclusion}

A feminist approach to such conditions of insecurity analyses enactments of exclusion at the intersection of gender and nation. Gender identity cannot be neatly extracted and treated as separate from national identity or class identity. In Sri Lanka, the production of difference through alliances of nation and class has also played an important role in fuelling competing Sinhala, Tamil and Muslim nationalisms. Nationalist discourses are gendered, to be sure; what it means to be a man or a woman is shaped by the politics of militarised nationalism-be it Sinhala or Tamil. We contend that a feminist analysis conceives of gender as mutually constituted with national identity, class and geographical location, but also as an expression of nationalist discourse. Conflict destabilises gender and other social relations; it also generates new patterns of mobility and meanings of place. While war may generate openings for women and men to renegotiate their work, mobility, and relation to one another, it also heightens uncertainty and insecurity for those displaced by the war.

In this article, we have examined three sites at which relations of nation, gender, and conflict intersect. Two kinds of displacement have been noted. On one hand, civilians displaced from the conflict seek safety at the UN Open Relief Centre which capitalizes on the long history of pilgrimage and sanctuary at the Shrine. A gendered division of displacement balances demands for livelihood with security, generating an state of 'mobile displacement' in and around Madhu. On the other, intentional acts of self-displacement characterise the performances of those (primarily Tamils) who perceive risk and experience fear at the checkpoints that dotted major roads in Sri Lanka during 1999-2000. People's speech, dress and 'presentation of self' were all key strategies to ensure security and pass the various checkpoints that dotted the Sri Lankan road network. In the first case mobility is expressed as displacement, although we do not suggest that displaced people lack volition and are only 'acted upon'. In the second instance, mobility is possible in so far as people marked as potential threats to the state are able to downplay or offset ascribed, fixed identities. The potential to 'pass' through the checkpoints requires the repetition of regulatory regimes, so that one avoids abject displacement, defined by Butler (1993, p. 155) as 'that which is excluded or marginalised by the construction of a subject position.' It is such exclusionary operations, both tangible and intangible, that are crucial to the formation of national, gendered subjects in Sri Lanka (Butler, 1992; cf. Scott, 1988). Checkpoints have, however, become sites for staging one's preferred identity and for deploying 'tactics of anticipation' that perform Tamilness as Sinhalaness. Such tactics sometimes make explicit and at other times disrupt the interpellatory scripts of Butler's regulatory fictions by acknowledging the everyday survival strategies of people already displaced based on their minority status. The trajectory of feminist politics that we have sought to explore here insists on the tracing of these performances, their constructions and erasures in an effort to capture the visceral insecurity and constrained mobility of people displaced by conflict.

\section{Acknowledgements}

We thank Karen Jacobson and Sue Lautze for providing us with an opportunity to present this paper at TUFTS University. We also acknowledge the several fascinating discussions we had with Pradeep Jeganathan and various interview- 
ees regarding identity cards and checkpoints. Three anonymous reviewers provided very useful comments for which we are grateful. Thanks also to James McLean for his careful reading and feedback. This paper could not have been written without the invaluable cooperation and support we received, while doing fieldwork in Sri Lanka, from both Oxfam personnel as well as participants in and from various NGO projects.

\section{Notes}

1. The Wanni is not noted on our map as it is not a place name, but a large region of northern Sri Lanka. During the period of our research, it stretched northward from just north of Vavuniya to the Jaffna Penninsula and from west coast to east coast. The southern 'border area', or boundary, shifted often as the front line of conflict moved with it, with the LTTE controlling most of the Wanni during the period of our research.

2. As in Bosnia-Hercegovina, 'Muslim' in Sri Lanka refers as much to an ethno-cultural group as one's faith; see Ismail (1995).

3. We encountered the language of 'beneficiaries' often, and found it contrary to the principles of feminist politics. It implies a clear hierarchy between donor and recipient and suggests a relationship of dependency between humanitarian/development organisations and a specified 'vulnerable' group.

4. In November 2003 a power struggle ensued between the Sri Lankan President and Prime Minister, who belong to opposing political parties; Sri Lankan President Chandrika Kumaratunga launched a constitutional coup and declared a state of emergency while Prime Minister Ranil Wickremasinghe was visiting Washington DC. The President argued that the Wickremasinghe government had been too soft on the LTTE. This led to the suspension of Norwegian-led peace talks in the country. Talks between the President and Prime Minister are ongoing, as we write this.

5. We canvassed both development-based organisations and humanitarian agencies, but found that the former did relief and rehabilitation work with displaced groups and the latter engaged in income generation and social development programmes. Hence, we use the development and humanitarian monikers interchangeably.

6. See Wilson (1988) for a thoughtful extrapolation on regional Tamil male identities with reference to the constitution of the Federal Party in Sri Lanka, and see Ismail (1995) for a discussion of regional variations in identity construction and politicization among primarily elite Muslim men.

7. There is a distinct geography of membership in the Mothers' Fronts that formed across Sri Lanka. Membership of the southern Sri Lankan Mothers' Front was primarily Sinhala and came from the working classes and the peasantry, whereas the members of the Fronts in the North and East were primarily Tamil and more diverse in terms of class. For a problematisation of the processes of such ethnic exclusivity see de Alwis, 1997.

8. The term 'Welfare Centre' itself is a misnomer which will become clear from our discussion; the displaced who lead miserable existences within these centres are quite clear that it is not their 'welfare' that is the central concern of the Sri Lankan state.

9. We would like to acknowledge the insights and analysis that Dag Sigurdson, Officer in Charge for UNHCR in Madhu, shared with us during both our 1999 and 2000 visits.

10. Ironically, many of these menacing steel grates are covered in advertising. They are so commonplace, and so widely seen by the public, that it must pay to publicise. These checkpoints have also sparked a new art form entitled 'barrelism' by installation artist Chandragupta Thenuwara, who uses similarly camouflaged barrels to critique the militarisation of Sri Lankan society.

11. The interviewee told us that on one occasion, while in possession of his national identity card, he was jailed overnight on no charge. Through personal connections, he was able to secure his release the next day. He was genuinely surprised that, despite being Tamil, his social standing and class markings did not exempt him from this experience.

12. In Kenya's Northeast Province where Somali refugees live in three main camps, there is a desire to pass as Kenyan from time to time. Travel and access to local employment is facilitated by having a Kenyan identity card, and with such demand, there is an entire economy in counterfeit documents (Hyndman, 2000).

13. Both these interviewees were trilingual, and while this is not necessarily a class marker per se, it does denote a certain amount of privilege and education. Both these interviewees did express 
considerable anxiety about not being able to write in Sinhala. This proved to be the one skill they did not have that could betray them when they tried to pass.

14. One of the most moving examples is a Tamil man who has lived through many anti-Tamil riots and refuses any longer to 'perform his Tamilness as Sinhalaness' through the mobilisation of what Jeganathan calls the 'master' tactic of anticipation' (Jeganathan 1998, pp. 99-100). He refuses to pronounce the Sinhala word baldiya (bucket) in the Sinhala way, rather than what is perceived to be the distinctively Tamil way of pronunciation, valdiya (p. 99) and is thus killed by a Sinhala mob as presented in Ernest MacIntyre's poignant drama, Rasanayagam's Last Riot (1993).

\section{References}

Abeysekera, Charles \& Newton, Gunasinghe (Eds) (1987) Facets of Ethnicity in Sri Lanka (Colombo, Social Scientists' Association).

Appadurai, Arjun (1996) Modernity at Large: cultural dimensions of globalization (Minneapolis, Mn, University of Minnesota Press).

Butler, Judith P. (1992) Contingent foundations: feminism and the question of 'postmodernism', in: Judith Butler \& Joan W. Scott (Eds) Feminists Theorize the Political, pp. 3-21 (New York/London, Routledge).

Butler, Judith P. (1990) Gender Trouble: feminism and the subversion of identity (New York, Routledge).

Butler, Judith P. (1993) Bodies that Matter: on the discursive limits of 'sex' (New York, Routledge).

Chatterjee, Partha (1986) Nationalist Thought and the Colonial World (London, Zed).

Chatterjee, Partha (1989) The nationalist resolution of the women's question, in: Kumkum Sangari \& Sudesh Vaid (Eds) Recasting Women: essays in colonial history, pp. 233-253 (New Delhi, Kali for Women).

Chatterjee, Partha (1996) Whose imagined community? In: G. Balakrishnan (Ed), Mapping the Nation, pp. 214-225 (London, Verso).

Cockburn, C. (2000) Women in black: being able to say neither/nor, in: Canadian Woman Studies special issue, 'Women in Conflict Zones', 19, pp. 5-10.

Cohn, Bernard (1987) The census, social structure and objectification in South Asia, in: An Anthropologist among the Historians and Other Essays, pp. 224-54 (Oxford, Oxford University Press).

Coomaraswamy, Radhika (1996) Tiger women and the question of women's emancipation, Pravada, 4, pp. 8-10.

Daniel, Valentine (1997) Suffering nation and alienation, in: Arthur Kleinman, Veena Das \& Margaret Lock (Eds) Social Suffering, pp. 309-358 (Berkeley, University of California Press).

de Alwis, Malathi (1994) Towards a feminist historiography: reading gender in the text of the nation, in: R. Coomaraswamy \& N. Wickremasinghe (Eds) Introduction to Social Theory, pp. 86-107 (New Delhi, Konark).

de Alwis, Malathi (1997) Motherhood as a space of protest: women's political participation in contemporary Sri Lanka, in: Amrita Basu \& Patricia Jeffrey (Eds) Appropriating Gender: women's activism and the politicization of religion in South Asia, pp. 185-201 (London/New York, Routledge).

de Alwis, Malathi \& Hyndman, Jennifer (2002) Capacity-Building in Conflict Zones: a feminist analysis of humanitarian assistance in Sri Lanka (Colombo, International Centre for Ethnic Studies).

de Mel, Neloufer (1998) Agent or victim? The Sri Lankan woman militant in the interregnum, in: Michael Roberts (Ed.) Sri Lanka. Collective identities revisited, volume 2 (Colombo, Marga).

de Silva, Mangalika (1994) Women in the Ltte: liberation or subjugation? Pravada, 3, pp. 27-31.

Debrix, François (1998) Deterritorialised territories, borderless borders: the new geography of medical assistance, Third World Quarterly, 19, pp. 827-846.

Fuglerud, Oivind (1994) 'Working for my sisters...-Tamil life on the 71st Parallel, Migration, 23-4, pp. 87-103.

Fuglerud, Oivind (1999) Life on the Outside: the Tamil diaspora and long distance nationalism. London: Pluto Press.

Giles, Wenona \& Hyndman, Jennifer (2004) Sites of Violence: gender and conflict zones (Berkeley, University of California Press).

Goffman, Erving (1959) The Presentation of Self in Everyday Life (Garden City, New York, Doubleday). Guha, Ranajit (Ed.) (1981) Subaltern Studies: writings on South Asian history and society, vol. I (Oxford/ Delhi, Oxford University Press).

Hasan, Zoya (Ed.) (1994) Forging Identities: gender, communities and the state (New Delhi, Kali for Women). 
Hellman-Rajanayagam, Dagmar (1990) The politics of the Tamil past, in: Jonathan Spencer (Ed.) Sri Lanka: history and the roots of conflict, pp. 107-122 (New York/London, Routledge).

Hensman, Rohini (1993) Journey Without a Destination (Colombo, Centre for Society and Religion).

Hyndman, Jennifer \& de Alwis, Malathi (2003) Beyond gender: towards a feminist analysis of humanitarianism and development in Sri Lanka, Women's Studies Quarterly, 31(3 \& 4), pp. 212-226.

Hyndman, Jennifer (2000) Managing Displacement: refugees and the politics of humanitarianism (Minneapolis, University of Minnesota Press).

Hyndman, Jennifer (2001) Towards a feminist geopolitics, Canadian Geographer 45, pp. 210-222.

Hyndman, Jennifer (2003) Aid, conflict, and migration: the Canada-Sri Lanka connection, Canadian Geographer, 47, pp. 251-268.

Hyndman, Jennifer (2003) Preventive, palliative, or punitive? Safe spaces in Bosnia-Herzegovina, Somalia, and Sri Lanka, Journal of Refugee Studies, 14, pp. 167-185.

Ismail, Qadri (1995) Unmooring identity: the antimonies of elite Muslim self-representation in modern Sri Lanka, in: Pradeep Jeganathan \& Qadri Ismail (Eds) Unmaking the Nation: the politics of identity and history in modern Sri Lanka, pp. 55-105 (Colombo, Social Scientists Association).

Jayawardena, Kumari \& de Alwis, Malathi (1996) Introduction, in: Kumari Jayawardena \& Malathi de Alwis (Eds) Embodied Violence: comunalising women's sexuality in South Asia, pp. ix-xxiv (New Delhi, Kali for Women).

Jayawardena, Kumari (1986) Feminism and Nationalism in the Third World (London, Zed Books).

Jayawardena, Kumari (1993) Some aspects of religious and cultural identity and the construction of Sinhala Buddhist womanhood, in: Douglas Allen (Ed.) Religion and Political Conflict in South Asia, pp. 161-180 (Delhi, Oxford University Press).

Jayawardena, Kumari (1995) The White Woman's Other Burden: Western women and South Asia during British colonial rule (New York/London, Routledge).

Jayawardena, Kumari (2002) Nobodies to Somebodies: the rise of the colonial bourgeousie in Sri Lanka (London/New York, Zed Books).

Jeganathan, Pradeep \& Ismail, Qadri (1995) Introduction: unmaking the nation, in: Pradeep Jeganathan \& Qadri Ismail (Eds) Unmaking the Nation: the politics of identity and history in modern Sri Lanka, pp. 2-9 (Colombo, Social Scientists' Association).

Jeganathan, Pradeep (1997) All the Lord's men? Recollecting a riot in an urban Sri Lankan community, in: M. Roberts (Ed.) Sri Lanka: collective identities revisited, pp. 221-245 (Colombo, Marga Press).

Jeganathan, Pradeep (1998) In the shadow of violence: 'Tamilness' and the anthropology of identity in southern Sri Lanka, in: Buddhist Fundamentalism and Minority Identities in Sri Lanka, pp. 89-105 (Albany, State University of New York Press).

Jeganathan, Pradeep (2002) Walking through violence: 'everyday life' and anthropology, in: Diane Mines \& Sarah Lamb (Eds) Everyday Life in South Asia, pp. 357-365 (Bloomington, Indiana University Press).

Jeyaraj, D.B.S. (1999) The mystique of Madhu, The Island, March 31.

Kanapathipillai, Valli (1990) July 1983: the survivor's experience, in: Tessa J. Batholomeusz and Chandra R. de Silva (Eds.) Mirrors of Violence: communities, riots and survivors in South Asia, pp. 321344 (Oxford, Oxford University Press).

Lefebvre, Henri (1991) Critique of Everyday Life, translated by John Moore (London/New York, Verso). Macintyre, Ernest (1993) Rasanayagam's Last Riot (Sydney, Worldlink).

Malkki, Liisa (1995) Purity and Exile: violence, memory, and national cosmology among Hutu refugees in Tanzania (Chicago, University of Chicago Press).

Massey, Doreen (1991) A global sense of place, Marxism Today, June, pp. 24-29.

Massey, Doreen (1993) Power-geometry and a progressive sense of place, in J. Bird, B. Curtis, T. Putnam, G. Robertson \& L. Tickner (Eds) Mapping the Futures: local cultures, global change, pp. 59-69 (New York, Routledge).

Maunaguru, Sitralega (1995) Gendering Tamil nationalism: the construction of 'woman' in projects of protest and control, in: P. Jeganthan \& Q. Ismail (Eds) Unmaking the Nation: the politics of identity and history in modern Sri Lanka, pp. 158-175 (Colombo, Social Scientists' Association).

Mcdowell, Chris (1996) A Tamil Asylum Diaspora: Sri Lankan migration, settlement and politics in Switzerland (Providence, Berghahn Books).

Moghadam, Val (1994) Introduction and overview, in: Val Moghadam (Ed.) Gender and National Identity, pp. 1-17 (London/New Jersey, Zed).

Perera, Jehan (1998) Mannar's unique 'zone of peace', The Island, 25 November.

Perera, Jehan (2003) LTTE's reciprocal commitment to an interim administration, Daily Mirror, 14 July. Peterson, V. Spike (1992) Security and sovereign states: what is at stake in taking feminism seriously, 
in V.S. Peterson (Ed.) Gendered States: feminist (re)visions of international relations theory (Boulder, Co, Lynne Rienner).

Peterson, V. Spike (1996) Shifting ground(s): epistemological and territorial remapping in the context of globalization(s), in E. Kofman \& G. Youngs (Eds) Globalization: theory and practice, pp. 11-28 (London/New York, Pinter).

Pettman, Jan Jindy (1997) Body politics: international sex tourism, Third World Quarterly, 18, pp. 93108.

Pratt, Geraldine (1998) Geographic metaphors in feminist theory, in: Susan Hardy Aiken, Ann Brigham \& Sallie A. Marston (Eds) Making Worlds: gender, metaphor, materiality, pp. 13-30, (Tucson, University of Arizona Press).

Pratt, Geraldine (2004) Working Feminism (Edinburgh University Press), .

Refugee Council (2002) Sri Lanka: return to uncertainty, Sri Lanka Project, London, July; accessed 3 October, 2002 〈http://www.refugeecouncil.org.uk/downloads/rc_reports/ srilanka_uncertainty.pdf).

Reuters (1999) Impasse on supply route to northern Sri Lanka, LacNet news service, 15 July.

Sangari, Kumkum \& Vaid, Sudesh (Eds) (1989) Recasting Women: essays in colonial history (New Delhi, Kali for Women).

Scott, Joan (1988) Gender and the Politics of History (New York, Columbia University Press).

Spencer, Jonathan (Ed.) (1990) Sri Lanka: history and the roots of conflict (London/New York, Routledge). Stasiulus, Daiva (1999) Relational positionalities of nationalisms, racisms, and feminisms, in: C. Kaplan, N. Alarcon \& M. Moallem (Eds) Between Woman and Nation: nationalisms, transnational feminisms, and the state, pp. 182-218 (Durham and London, Duke University Press).

Steen, A. B. (1993) Varieties of the Tamil Refugee Experience in Denmark and England (Copenhagen, University of Copenhagen and The Danish Centre for Human Rights).

Tickner, J. Anne (2001) Gendering World Politics: issues and approaches in the post-Cold War era (New York, Columbia University Press).

Tiruchelvam, Neelan (1996) Sri Lanka's Ethnic conflict and preventive action: the role of NGOs, in: R. Rotberg (Ed.) Vigilance and Vengeance: NGOs preventing ethnic conflict in divided societies, pp. 147-164 (Washington DC, Brookings Institution).

United Nations High Commissioner For Refugees (UNHCR) (1990) UNHCR Policy on Refugee Women, Geneva, August.

United Nations High Commissioner For Refugees (UNHCR) (1991) Guidelines on the Protection of Refugee Women, Geneva, July.

Wilson, A. J. (1988) The Colombo man, the Jaffna man, and the Batticaloa man: regional identities and the rise of the Federal Party, in: C. Manogaran \& B. Pfaffenberger (Eds) The Sri Lankan Tamils: ethnicity and identity (San Francisco, Westview Press).

Yuval-Davis, Nira (1998) Gender and Nation (London, Thousand Oaks, New Delhi: Sage). 